\title{
Problems and Prospects of Woman Entrepreneurship - A Review of Literature
}

\author{
Sonu Garg ${ }^{1}$, Dr. Parul Agarwal ${ }^{2}$ \\ ${ }^{1}$ (Research Scholar, School of Management, JECRC University, Jaipur, Rajasthan, India) \\ ${ }^{2}$ (Dean, School of Management, JECRC University, Jaipur, Rajasthan, India)
}

\begin{abstract}
Any nation, to grow today in the world of intense competition, requires entrepreneurs at the core of the economic development. Entrepreneurial activities and entrepreneurship has been dominated by males since ages. However, in the era of information technology, the women have become more aware and better educational facilities have enabled them to venture into this male dominated space. The women today have emerged as a key player in economic development of the nations. However this transformation of society is far from over and the women entrepreneurs not only face difficulties while starting up an enterprise but also during the running phase. Globally, they have become a key player in sustaining both social development and economic growth. However, in a country like India where almost 50\% of population is made up of women, the number of enterprises run by women entrepreneurs is only $7.36 \%$ or out of 361.76 Lakh enterprises in the MSME sector, only 26.61 Lakh have women at the top. There are a number of socio-economic hurdles faced by the women while they attempt to venture into setting up and running their own enterprises. Hence, the paper discusses the status of the Women Entrepreneurs and their importance. Also, an attempt is made to identify the challenges faced by these women entrepreneurs, by reviewing various literatures and provide some suggestion for overcoming these obstacles.
\end{abstract}

Keywords: Women Entrepreneurship, Women Entrepreneurs, Challenges, MSME, Finance

\section{Introduction}

An entrepreneur is a person who is involved in economic activity and takes an initiative to start a business with innovative ideas. Entrepreneurship provides huge opportunities for self - expansion as well as serves the society. All over the world, entrepreneurs provide vast employment opportunities by setting up Micro, Small and Medium enterprises in urban, semi - urban and rural areas for uplifting the living standard of people. The phenomenon of women entering the entrepreneurial arena is in the early stage as businesses have been male dominated and women have always engaged in homely affairs i.e cooking and nurture the family and children. Over the last few years, the scenario has changed and the women have come to the forefront as not only memorable but also as inspirational entrepreneurs. Entrepreneurship as such is not bound by the class, religion, community, gender or age and hence any person can start a business today. ${ }^{1}$

In past few years, women entrepreneurs have been involved significantly in the development and social progress of the country due to industrialization, urbanization along with education and awareness. This opens up ample opportunities for the nation, society and the family. Setting up their own ventures not only makes them self-sufficient and self-dependent but also enables them to create their own social identity. This way they have been able to achieve work-life balance and contributed to the satisfaction of their customers by involving themselves in the innovation of the products ${ }^{2}$ also they have been able to empower people economically. Various sources of data confirm the contribution of this new generation of entrepreneurs i.e. the women entrepreneurs play a crucial role in the economies across the world. ${ }^{3}$ In U.S., 1.5 trillion dollars worth of sales is generated by more than 9 million firms owned by the women entrepreneurs ${ }^{4}$, whereas women own more than 26.6 lakh MSME units in India. Women have entered into the manufacturing, service and trading sector and thus their role has gone beyond some selected professions. Clearly, in the economic development of the nation, the role of a women entrepreneur has become significant. This has resulted into more focus in creating a healthy environment for establishing and smooth running of women led MSMEs by the government of India. There have been several steps taken in this direction by the government in the recent past and as a result, the number of enterprises, owned by women, has been steadily increasing. Nearly $10 \%$ of the MSMEs in India are owned by women entrepreneurs.

Special incentives and subsidies have been provided to the women - owned MSMEs by the government of India, yet there is a huge gap existing between the male and female entrepreneurs is to be covered. Obstacles are faced at every stage of setting up business by this group of entrepreneurs. Hence, the purpose of this paper is to discuss the need of women entrepreneurs, identify the challenges faced by these women entrepreneurs by reviewing various literatures and provide some suggestion for overcoming these obstacles. 


\section{Status Of The Women Entrepreneurs In India}

Women Entrepreneurs may be defined as a group of women who initiate, organize and operate a business or enterprise. The Government of India has defined women owned enterprises as - "an enterprise owned and controlled by women having a minimum financial interest of 51 percent of the capital and giving at least 51 per cent of the employment generated in the enterprise to women", ${ }^{6,7}$ In the early $90 \mathrm{~s}$, the entrepreneurial activity was dominated by men and the involvement of women was limited to household jobs and agricultural activity. ${ }^{8}$ In a situation where the earning male member is no more or left, the family would be a big loser. ${ }^{9}$ As per 2001 census; women constitute nearly half of India's population of which, $72 \%$ were engaged in agriculture, $21.7 \%$ in non agricultural jobs and remaining in household industries. ${ }^{10}$ However, the introduction of the policy of globalization and with the promotion of privatization during the mid - 90s, the women started venturing into this male dominated area of entrepreneurial activity. ${ }^{8}$ Today, they not only guide but also head several industries. Various pull and push factors have led to the involvement of women in business activity as this not only makes them financially independent but also results into higher self - belief and confidence. The women today have started venturing to the MSME space in big ways setting up their own ventures. ${ }^{6}$ On one side, factors like low income, strict working hours, need, lack of job opportunities or job satisfaction, work-life balance, etc. lead the women to take up entrepreneurial activity, whereas on the other hand better financial opportunity, desire to help others and attaining self accomplishment motivates a women to take up entrepreneurial activity. ${ }^{11}$

In India, 26.61 lakh enterprises are female - owned out 361.76 lakh enterprises in the MSME sector whereas 120 lakh employees are female out of 805 lakh employees as per the MSME annual report 2014-15. As per business report 2014 and survey done by IFC, women - owned enterprises contributes $3.09 \%$ of industrial output and employ over 8 million people ${ }^{12}$ However, the growth of female - owned enterprises in India is relatively lower when compared with the other developed and developing countries. As per the report of Female Entrepreneurship Index by the Global Entrepreneurship and Development Institute, in a survey of 77 countries, India ranks 70, just above Ethiopia, Iran and Ugandan which shows that in India, there is no adequate environment for women entrepreneurship development and their growth. While the number of women operating their own business is increasing globally, Indian women entrepreneurs continuously face huge obstacles in the growth path of their businesses, such as insufficient initial and working capital, strict social constraints and limited time and low skill. ${ }^{5}$

\section{Need Of The Women Entrepreneurship}

As per the 2011 census, Indian population comprises of $48 \%$ women. $34 \%$ of the population participates in the financial and economic activities with many of them not being paid. ${ }^{13}$ In the case of an unfortunate event of losing the earning member, they are heavily dependent and the survival of the family is at stake. Hence, promoting women entrepreneurship is an important activity that any society should promote.

Involvement of women has its inherent benefits for the industry as well as society. Professionally, the women entrepreneurs setting up their own firms help in create new employment opportunities and per capita income of the nation is increased. Socially, they become independent, provide a better and brighter future for the next generation as well as family, better education and awareness levels, more confident about themselves and are in a better position to manage family businesses in case of loss of the earning member. ${ }^{14}$ The major reason that attracts women to begin as an entrepreneur is that they have innovative ideas and ability to do something creative which helps their individual identity to be recognized at not only local or national but at a larger also global level. ${ }^{15}$

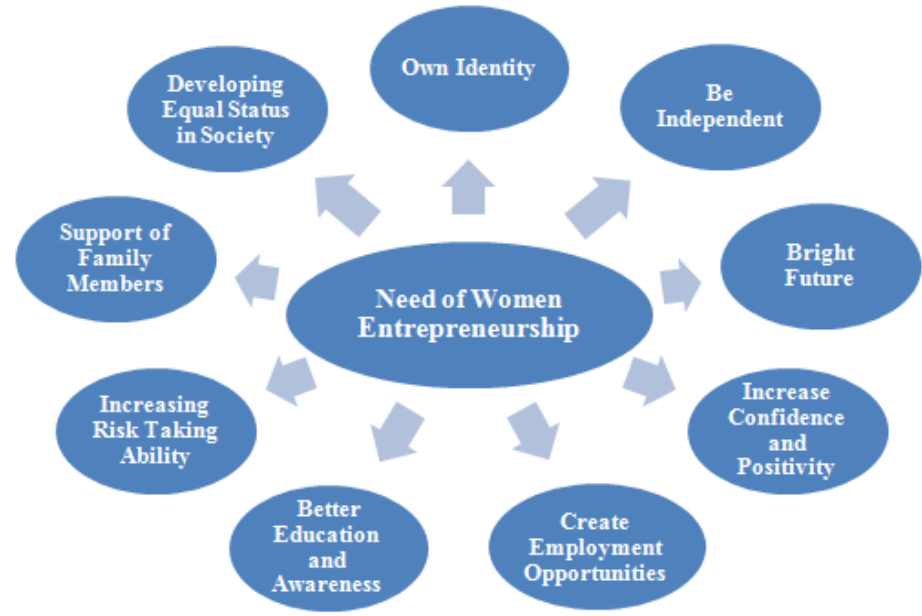

Figure 1: The Need of Women Entrepreneurship 


\section{Problems Faced By Women Entrepreneurs}

4.1. Lack of Education: Searching for opportunities, ability to examine and understanding them and building a successful business around this opportunity are the essential traits of an entrepreneur and to be able to do this, education is an important factor. It has been experienced that the female population in developed countries are more educated as compared to their counterparts in developing countries. ${ }^{16}$ In India, the situation is that the 56\% of female population is literate with majority of them not even having education beyond school. This leads to a scenario where the women entrepreneurs are not adequately equipped to the latest developments in technology or market, let alone being aware about new business opportunities. Thus, women entrepreneurs run into a number of problems while setting up and operating their businesses due to this deficiency. ${ }^{17}$

Table 1: Literacy Rate in India

\begin{tabular}{|l|l|l|l|}
\hline & Total & Male & Female \\
\hline Population (In Crore) & 121.09 & 62.33 & 58.76 \\
\hline Literate (In Crore) & 76.36 & 43.48 & 32.89 \\
\hline Literacy \% & $\mathbf{6 3 . 0 7 \%}$ & $\mathbf{6 9 . 7 6 \%}$ & $\mathbf{5 5 . 9 7 \%}$ \\
\hline Literacy as \% of Total Population & - & $\mathbf{3 5 . 9 1 \%}$ & $\mathbf{2 7 . 1 6 \%}$ \\
\hline
\end{tabular}

Source: General Census $2011^{13}$

There is an $8.75 \%$ gap in the literacy rate at the national level. $89.57 \%$ of the literate population is educated to higher secondary or below levels. Only $9.07 \%$ of the total female literate population as against $11.47 \%$ of their male counterparts has an education of above higher secondary and hence a lot of work is required to be done to enable women population to get higher education and equip them to venture into entrepreneurship.

4.2. Social Barrier: Gender discrimination, fear of reaction from the society, family responsibilities and commitments are some of the factors that combine together to make a social barrier for women to venture into entrepreneurship. Women in India are treated as subordinates and an live as dependents to men and thus it is assumed that entrepreneurship is not the subject of women as it is a total preserve for men. ${ }^{18,17}$ The duties, responsibilities and obligations towards family is considered to be acting as a barrier for women to take up entrepreneurship. Various surveys show that this attitude is a result of pressures brought by the conservative thinking of a traditional society as the women are expected to prioritise delivery on family front as against any other activity. ${ }^{19}$ It is more visible and prominent in rural areas where the traditional role of women results into almost no or less time to be spared for business activities. ${ }^{5}$ The women are made to feel guilty in case there is any lapse towards family duties thus indicating the lack of family support and commitment towards the development of women in society. ${ }^{19}$ This also restricts a woman from setting up and running a business, visiting banks, attending entrepreneurship development training courses and seminars and conferences, attracting customers or looking for diversified suppliers. ${ }^{20}$

4.3. Financial Problem:The Financial problem of businesses is related to shortage of adequate finance, difficulties in obtaining credit from banks, Low risk-bearing capacity, problem in capital for expansion, unaware about appropriate finance sources, lack of collateral, complex and lengthy loan procedures, etc. In India, women entrepreneurs always suffer from inadequate and inappropriate finance resources. They are unable to acquire finance from external sources such as formal financial institutions due to low creditworthiness and absence of accurate collateral as women have very less property and bank balance in their name. ${ }^{5,18,17}$ Research done by Robert in non-OECD and developing economies reveals that 59 percent of the respondents have mentioned financial problem as crucial problem followed by $41 \%$ having difficulty in obtaining a loan.

Sandhu, (2012) discussed in his research that bank official takes a final decision on a loan application of women entrepreneurs when female owners provide collateral and have given a letter of guarantee from blood relation or husband or a head of the village for setting up enterprises. It is normally believed that women being feminist gender have low risk taking ability. ${ }^{21}$ Thus, women entrepreneurs start a business with a very low level of capitalisation and low level of debt finance and do not use much of private equity for their business sustainability due to unfavourable internal and external conditions of them ${ }^{22}$, This financial exclusion is due to voluntary and involuntary reasons. Women entrepreneurs have voluntarily excluded from banking services due to lack of literacy as well as complex and lengthy procedures of bank loans. ${ }^{23}$ On the other hand, involuntary exclusion from financial services is happening as banks are not interested to provide loan facilities due to high interest rate, low level of credit worthiness, absence of past credit history, low level of credit bearing capacity and unhealthy relationship with banks while availing bank credit. ${ }^{22}$ In addition, women entrepreneurs are not aware of financial assistance i.e. subsidies, incentives, tax relief etc. provided by the financial institutions and government which result into business failure. ${ }^{6,24}$ This results into women becoming more dependent on her small savings and loan from family and friends for their day to day operations which is not sufficient for business sustainability. 
4.4. Personal Barriers: Personal barrier are related to women entrepreneurs in their personal capacity or their own mental blocks that stops them from taking risks and starting businesses. Also, general assumption about women characteristics in the society like lack of entrepreneurial aptitude, lack of self - confidence and fear of failure, problem of gaining confidence and support from other businesses, lack of involvement with business colleagues etc. acts as personal barriers.

4.4.1. Self - confidence and fear of failure - The general assumption is that globally, men are much optimistic and confident than women in terms of their business opportunities and running a business. ${ }^{25}$ The lack of self confidence is the one of the crucial problems to women who want to perform entrepreneurial activity into micro and small enterprises. ${ }^{26,}{ }^{24}$ It is considered that the self- confidence level in women is less as compared to women in general. However, the level of confidence varies from person to person and situation to situation and hence this may not hold true when it comes to self-confidence in handling entrepreneurial activities. ${ }^{27}$ Female owners though have a fear of failure and this has been related to the social and economic challenges faced by them as per a research carried by Halkias et al.,. ${ }^{28}$ Some researches show that women may be able to come over this barrier and enhance their level of self - confidence by participating in various entrepreneurial training programmes, workshops and seminar conducted by government and government departments.

4.4.2. Lack of entrepreneurial aptitude - Lack of entrepreneurial aptitude and behaviour is one of the personal barriers in the way of start and grow of any business activities. Generally, upbringing of women is not as well as men with respect to business understanding and thus, they have no entrepreneurial bent of mind even after participating in a number of entrepreneurship development programmes and training, workshops, seminar etc. Only some of the women start and runs the business after improving on their pessimistic attitude towards entrepreneurship or compulsion and increase risk bearing capacities and calibre.

4.5. Market Related Barrier: Marketing is an organizational function that creates, communicates and delivers value to customers. ${ }^{29}$ However, strong competition, weak marketing network, poor sales strategies, delays in payment by clients, lesser marketing experience and rapid change in demand and technology are the factors that pressure the women enterprises to respond quickly to changing market scenario. ${ }^{30,31}$

In general, Women - owned micro, small and medium enterprises have been surviving under stiff competition from establish firms and male entrepreneurs in term of cost, quality, standards and meeting the dynamic demand of customers. Also, male entrepreneurs have much experience, knowledge of the market and adopt new technology in their production. But as women start their business with small saving and small investment thus, they do not have adequate money to spend the advertisement of their products and services. Thus, females entrepreneurs have been doing limited marketing activities, mostly depends on middle men i.e. distributors, retailer etc. who try to take a major part of margin resulting into less profit for the firm. This results into less money for expansion and upgradation of technology. Inferior and inefficient technology produces low quality and costlier products making them uncompetitive in the market which is one of the major reasons for failure of the business. ${ }^{24,32}$ Networking in their own social network is another way to market products as this is less costly and an emotional touch is there. Also, it would enable them to have access to information and make it easier for the women entrepreneur to easily access customers, suppliers and financial resources from close connections rather than business co-operators or colleagues. ${ }^{30}$

4.6. Skill Related Barrier: Higher technical and general managerial skills are the quality which an entrepreneur obtains during his or her life during the course of entrepreneurial training and education received and prior industrial and managerial experience. This enables the entrepreneur to discover and exploit better career or business opportunities. However, women entrepreneurs in India and several other developing countries have been facing barriers related to skill i.e. lack of prior managerial and industrial experience, lack of technical and general skill, inadequate and timely entrepreneurial training and education, etc. ${ }^{33,34}$ These barriers create obstacles in the growth and development of women - owned enterprises. Also, women entrepreneurs in India do not having sufficient time to enhance their skill related ability by attending entrepreneurial programmes due to several social barriers. Government and Ministry of MSME have taken several initiatives by conducting Entrepreneurship Development Programmes (EDPs), Entrepreneurship cum Skill Development Programmes (ESDPs) and Training of Trainers (ToTs) programmes in the areas of Entrepreneurship and Skill Development. ${ }^{35}$ During the year 2015-16, 4,818 and 27, 557 women had trained by NI- MSME and NSIC respectively through various training programmes. The inability to attend such training programmes and workshops due to social barriers limits the managerial capabilities of the women entrepreneurs. The women entrepreneurs are less efficient when it comes to executing various functions like planning, marketing, motivation of work force, controlling and co-ordinating between various business functions, etc.. ${ }^{18}$ 
4.7. Operational Barriers: Women entrepreneurs are given a similar type of training by the EDPs, irrespective of the firm being a start-up or old. This results into severe lack of knowledge for running a business. Second generation women entrepreneurs already have an exposure to business and therefore, need guidance and advisory to manage the unpredictable situation, which may arise, due to unexpected events, economic or political. ${ }^{32}$ One such example is of demonetisation where the cash was not at disposal and hence the purchasing power of individuals has dropped. Also, a number of agencies have business development programmes for startup phase, but once the business is established, the women entrepreneurs are left on their own to compete in an environment that does not provide a level playing field. ${ }^{22}$ The women entrepreneurs severely lack on the experience of operating a business and hence counseling, guidance, mentoring and advisory services can help them overcome the barriers faced by them while operating a business that was set-up with a lot of hard work and make it successful.

4.8. Other barriers: Some of the other barriers caused by the barriers mentioned above or due to a combination of above barriers are mentioned below.

$>$ Obsolescence of Technology / Technological Development Problems

$>$ Legal Formalities

$>$ Shortage of Raw Materials

$>$ Lack of Government Support/ Cumbersome Government Procedures

$>$ Lack of Availability of Motivational Factors

$>$ Direct and Indirect Tax-related Issues

$>$ Location of Business

$>$ High Turnover of Staff

$>$ Lack of Awareness about Government Schemes and Policies.

In spite, of so many hurdles, the women today are venturing into any and every field including trading and manufacturing. Any nation with a large population of females, like India, cannot ignore the hidden potential and hence, much - needed support both from society and the government authorities is required. This would help the nation's economy to grow at much faster pace and contribute to reducing a major issue faced by the nation, unemployment.

\section{Conclusion And Recommendations:}

Today's women have ventured into manufacturing, trading and service sector from the earlier days where they were limited only to the domestic jobs. The participation of women in the entrepreneurial activity makes them not only self - confident but also self - dependant. Thus, it provides them an opportunity of not only contributing to the economic development of the nation, but also enables them to give a better life to their family.The women make up for almost 50\% of the population in India, however, only $10 \%$ of the firms in the MSME sector are owned by them. Hence, if supported, the women entrepreneurs can provide a much - needed boost to the economy by creating new employment opportunities. The women - owned firms have more than doubled from 1.02 million enterprises in $2001-2002$ to 2.66 million in $2005-2006$, the percentage of registered firms owned by women increased from $8.32 \%$ to $13.72 \%$.

However, they face a number of barriers in the quest of achieving their ambition. They face social barriers right in the beginning of the start - up phase followed by the financial barriers. Market and skill related barriers make it more difficult for them to begin their entrepreneurial ventures. Barriers created by their own fears and attitude towards taking decisions for starting the business is another factor for the dismal percentage of women - owned enterprises. However, amidst a lot of difficulties, they have proven their ability to manage not only small businesses but also convert them into highly successful large industries. Biocon Pharmaceuticals is one such example.A proper environment with support from society, primarily their own family, and government can solve many of the issues and as such, government has rolled out several initiatives and schemes to help women entrepreneurs to overcome these barriers. Various initiatives have been taken in $7^{\text {th }}, 8^{\text {th }}$ and $9^{\text {th }}$ five - year plans by making the women entrepreneurs a target group and developing schemes around this group. There are numerous schemes, wherein women receive additional benefits/concessions/assistance such as PMEGP; also M/o MSME is executing two specific schemes for women i.e. TREAD and Mahila Coir Yojana. Mahila Vikas Nidhi and Rashtriya Mahila Kosh were funds setup in accordance with the provisions in the $9^{\text {th }}$ five year plan for providing financial assistance to the women entrepreneurs. Also, with higher education and increasing literacy rates, the view of the society is also changing towards venturing of women into entrepreneurial activities. In the constantly changing scenario, the government should not only spread awareness at a large scale about various initiatives for women entrepreneurs but also setup dedicated centres for helping women entrepreneurs. Also, a single window setup for women entrepreneurs staffed with well informed and skilled personnel could help the women entrepreneurs to manage the cumbersome government procedures, manage tax related issues and complete legal formalities. Designing training programmes and workshops, more relevant to today's scenario along with programmes addressing needs of the women entrepreneurs at various stages of the firm's life cycle would immensely help them by equipping them with skills and knowledge required to create a successful firm.

$\begin{array}{lll}\text { DOI: } 10.9790 / 487 X-1901065560 & \text { www.iosrjournals.org } & \text { 59|Page }\end{array}$




\section{References}

[1]. P.C. Jain, Handbook for New Entrepreneurs, New Delhi: Oxford University Press, 2003, 3-55.

[2]. S.Agarwal, and U. Lenka, An exploratory study on the development of women entrepreneurs: Indian cases, Journal of Research in Marketing and Entrepreneurship, 18(2), 2016, 232 - 247.

[3]. M. Minniti, P. Arenius and N. Langowitz, GEM 2004 Report on women and Entrepreneurship, Global Entrepreneurship Monitor, Babson College and London Business School, Babson Park, MA and London, 2005.

[4]. P. Fernandes, (2016 May 10), Challenges Women Entrepreneurs Face (and How to Overcome Them). Business News Daily Contributor. Retrieved from; http://www.businessnewsdaily.com

[5]. S. Mahajan, Women Entrepreneurship in Indi, Global Journal of Management and Business Studies. 3(10), 2013, 1143-1148.

[6]. M. Goyal and J. Prakash, Women Entrepreneurship in India - Problems and Prospects. Zenith International Journal of Multidisciplinary Research. 1(5), 2011, 195-207.

[7]. Y. Sharma, Women Entrepreneur in India, IOSR Journal of Business and Management (IOSR-JBM), 15(3), 2013, 09-14.

[8]. V. M. Chavan and P. A. Murkute, Role of Women Entrepreurship in Indian Economy, International Journal of Science Technology and Management, 5(3), 2016, 606 -612.

[9]. S. Mundra and J. Sharma, A Comparative Analysis of the Status of Women Entrepreneurship: India Vs. Global, Research Journal of Social Science \& Management, 3(4), 2013,147 -156.

[10]. Vinesh, Role of Women Entrepreneurs in India, Global Journal of Finance and Management, 6(5), 2014, 473-480.

[11]. A. Hossain, K. Naser, A. Zaman and R. Nuseibeh, Factors influencing women business development in the developing countries; Evidence from Bangladesh, International Journal of Organizational Analysis, 17(3), 2009, 202-224.

[12]. Anjali, M. V. (2015 May 19). Increasing women entrepreneurs: Challenges and solutions. Business Standard. Retrieved from; http://www.business-standard.com

[13]. General Census 2011. Retrieved from: http://www.censusindia.gov.in/2011census/C-series/C08.html

[14]. Importance of Women Entrepreneurship in India Retrieved from: http://wit.tradekey.com/news/india/importance-of-womenentrepreneurship-in-india_4143.html).

[15]. P. Mehta, Women Entrepreneurship: Purpose, Problems \& Prospects: A Study of Udaipur District, Pacific Business Review International, 5(11), 2013, 8-16.

[16]. R. Hisrich and M. Lerner, Israeli women entrepreneurs, Journal of Business Venturing, 12(4), 1997, $315-39$.

[17]. T. Vijayakumar and B. Naresh, Women Entrepreneurship In India - Role of Women in Small and Medium Enterprises, Trans Asian Journal of Marketing \& Management Research, 2(7), 2013, 13-24.

[18]. A.B. Siddiqui, Problems Encountered by Women Entrepreneurs in India, International Journal of Applied Research \& Studies, I (II), 2012, 1-11.

[19]. D. Jamali, Constraints and opportunities facing women entrepreneurs in developing countries; A relational perspective, Gender in Management: An International Journal. 24(4), 2009, 232-251.

[20]. K. Naser, W.M. Rashid and R. Nuseibeh, Factors that affect women entrepreneurs: evidence from an emerging economy, International Journal of Organizational Analysis, 17(3), 2009, 225 - 247.

[21]. N. Sandhu, J. Hussain and H. Matlay, Barriers to finance experienced by female owner/managers of marginal farms in India, Journal of Small Business and Enterprise Development, 19(4), 2012, 640 - 655.

[22]. A.M. Roomi, P. Harrison and J. Beaumont-Kerridge, Women-owned small and medium enterprises in England, Journal of Small Business and Enterprise Development, 16(2), 2009, 270 - 288.

[23]. J. Nehru and S. Bhardwaj, Women Entrepreneurship in India: Issues \& Problems "You Can Tell the Condition of a Nation by Looking at The Status of Its Women. Spectrum: A Journal of Multidisciplinary Research, 2(7), 2013, 8-16.

[24]. S. Nandy and S. Kumar, Women Entrepreneurship in 21st Century India, Global Journal of Finance and Management, 6 (9), 2014, 967-976.

[25]. P. Koellinger, M. Minniti and C. Schade, "Seeing the world with different eyes: gender differences in perceptions and the Propensity to start a Business, 2008.

[26]. S.L. Fielden, M.J. Davidson, A.J. Dawe, and P.J. Makin, Factors inhibiting the economic growth of female owned small businesses in North West England, Journal of Small Business and Enterprise Development, 10(2), 2003, 152-66.

[27]. C.K. Rozier and M. Thompson, Female entrepreneurs in a female-dominated health profession: an exploratory study, Journal of Developmental Entrepreneurship, 3(2), 1998, 149-63.

[28]. D. Halkias, C. Nwajiuba, H. Nicholas and S.M. Caracatsanis, Challenges facing women entrepreneurs in Nigeria, Management Research Review, 34(2), 2011, 221 - 235.

[29]. P. Kotler, K. L. Keller, A. Koshy and M. Jha, Defining Marketing for the 21st Century. Marketing Management-A South Asian Perspective, 6, Pearson Education, 2012.

[30]. F.S.M.A. Hasan and M.M.S. Almubarak, Factors influencing women entrepreneurs' Performance in SMEs, World Journal of Entrepreneurship, Management and Sustainable Development, 12(2), 2016, 82-101.

[31]. T.J. Marjanova and M. Stojanovski, "Marketing Knowledge and Strategy for SMEs: Can They Live Without It?" Retrieved from: http://www.eprints.ugd.edu.mk/id/eprint/2084

[32]. A. Vijayakumar and S. Jayachitra, Women Entrepreneurship in India - Emerging Issues and Challenges, International Journal of Development Research, 3(4), 2013, 12-17.

[33]. F. Azmat, Opportunities or obstacles? Understanding the challenges faced by migrant women entrepreneurs. International Journal of Gender and Entrepreneurship. 5(2), 2013, 198-215.

[34]. V. Kanti Prasad, G. M. Naidu, B. Kinnera Murthy, Winkel, Doan E. and K. Ehrhardt, Women entrepreneurs and business venture growth: an examination of the influence of human and social capital resources in an Indian context, Journal of Small Business \& Entrepreneurship, 26, 2013, 341-364

[35]. Annual Report 2015-16, Ministry of Micro, Small \& Medium Enterprises, Government of India.

[36]. Annual Report 2014-15, Ministry of Micro, Small \& Medium Enterprises, Government of India. 